\title{
Penerapan Teknologi Vermicomposting Dalam Pengelolaan Limbah Pertanian Di Desa Massila Kabupaten Bone
}

\author{
Application of Vermicomposting Technology in Agricultural Waste Management in \\ Massila Village, Bone Regency
}

\author{
Abri $^{1}$, Aylee Christine Alamsyah Sheyoputri ${ }^{2 *}$, Sanusi $^{3}$ \\ *Email: aylee.christine@universitasbosowa.ac.id \\ ${ }^{1}$ Program Studi Agroteknologi Fakultas Pertanian, Universitas Bosowa \\ ${ }^{2}$ Program Studi Agribisnis, Fakultas Pertanian, Universitas Bosowa \\ ${ }^{3}$ Program Studi Ilmu Ekonomi, Fakultas Ekonomi dan Bisnis Universitas Hasanuddin
}

\begin{abstract}
ABSTRAK
Desa Massila, Kecamatan Patimpeng, Kabupaten Bone, Sulawesi Selatan, memiliki potensi limbah pertanian yang sangat besar. Limbah jerami sering menjadi masalah karena hanya dibakar atau ditimbun sehingga menimbulkan pencemaran lingkungan, begitu pula limbah peternakan. Pengelolaan limbah pertanian dengan teknologi vermicomposting dapat menghasilkan dua kegiatan sekaligus yaitu usaha budidaya cacing dan usaha pembuatan pupuk kascing. Kegiatan ini diharapkan terwujudnya kegiatan pemberdayaan ekonomi masyarakat melalui pengembangan potensi dengan pemanfaatkan limbah pertanian dan kotoran sapi sehingga menjadi kelompok wirausaha baru yang produktif. Program Kemitraan Masyarakat ini dilaksanakan dengan menggunakan metode penyuluhan, workshop, pelatihan, pembimbingan, pendampingan, dan penerapan aplikasi teknologi tepat guna di lapangan dalam bentuk demplot. Hasil yang telah dicapai dalam pemberdayaan kelompok tani dalam usaha budidaya cacing dan kascing ini ialah (1). Anggota kelompok tani Mamminasae telah mampu melaksanakan dan memiliki keterampilan budidaya cacing tanah dengan tahapan kegiatan: pembuatan rak cacing bersusun, pembibitan, penggantian media, pemeliharaan, pengendalian hama dan penyakit, pemanenan cacing dan kascing (2). Terbentuknya unit usaha kelompok tani mandiri yang dapat memperoleh tambahan pendapatan, meningkatkan kualitas hidupnya, agar mereka dapat hidup lebih baik, lebih efisien cara hidupnya, lebih sehat fisik dan lingkungannya. (3). Budidaya cacing tanah setiap bulan dapat menghasilkan 10 karung kascing (karung $12 \mathrm{~kg}$ ) yang dijual dengan harga $\mathrm{Rp} \mathrm{20.000/karung} \mathrm{X}$ 10 karung $=$ Rp 200.000 untuk luas kandang 8 X 5 m dengan menggunakan rak bersusun. Sedangkan produksi cacing sendiri setiap bulan dapat menghasilkan cacing sebanyak $10 \mathrm{~kg}$ cacing/bulan dengan harga Rp 100.00 X $10 \mathrm{~kg}=\mathrm{Rp} 1.000 .000 /$ bulan + kascing Rp 200.000, sehingga total pendapatan tambahan yang diterima oleh kelompok tani Mamminasae sebesar Rp 1.200 .000
\end{abstract}

Kata Kunci: Potensi Limbah, Jerami, Kotoran sapi, Kascing, Kompos

\section{ABSTRACT}

Massila village, located at Pattimpeng, Bone Regency of South Sulawesi, produces agricultural wastes that have a lot of potentials. The straw waste used to be a problem because it was only burnt or buried, causing the damages on the environment. That also applies for the waste from farming activities. The implementation of the technology of Vermicomposting could generate two activities at the same time that consists of: 1) the cultivation of worm, and 2) the production of worm-based fertilizer that use the agricultural waste as the media. By these activities, it is expected that the economic empowerment of local citizens can be established through the development of the potentials of agricultural wastes and cows dungs, creating groups of productive local entrepreneurs. This partnership program with citizens is organized by using the methods of socialization, workshops, trainings, supervisory, and the implementation of the appropriate technology in the field that takes form of demonstration plot. The results gained from the empowerment of the groups of farmers in the cultivation of worms and fertilizers can be 
described in three achievements: 1) the members of the farming groups have gained the ability and skills in conducting the cultivation of earthworms that consists of several steps: the production of the multilevel medium for the worms, seeding, medium replacement, maintenances, the controlling of pest and plant disease, and the harvest of the worms, 2) the establishment of the independent groups of farmers that can produce additional incomes from the activities in order to increase their life's quality, so that they can live a better life, and in the healthier physical conditions and environments, 3) the cultivation of the earthworms can generate, per month, ten bags of worm fertilizer that have a weight of $12 \mathrm{~kg}$ per each, and has a price of Rp.20.000,- per unit. It is sold for ten bags, so it can generate Rp.200.000 in total for the area of $8 X 5 \mathrm{~m}$ of the multilevel cages. In other hand, the production of the earthworms per month itself could generate the worm approximately $10 \mathrm{Kg}$ per month with the price of Rp.100.000 per Kg. If it was sold for $10 \mathrm{Kg}$ (per unit bag), it generates $R p 1.000 .000$ per month. In total, the amount of total revenues gained by the groups of farmers in Mamminasae could reach up to Rp.1.200.000.

Keywords: Potential Waste, Straw, Cow Manure, Vermicompost, Compost

(c) (1) This work is licensed under Creative Commons Attribution License 4.0 CC-BY International license

\section{A. PENDAHULUAN}

Kualitas Desa Massila merupakan salah satu desa yang berada di wilayah Kecamatan Patimpeng, Kabupaten Bone, Sulawesi Selatan. Desa ini memiliki potensi pertanian dan peternakan yang cukup besar yaitu luas sawah 750 ha dan populasi ternak sapi sebanyak 1.539 ekor.

Dibalik potensi yang dimiliki ternyata masyarakat desa ini masih banyak permasalahan yang dihadapi di antaranya ketika saat panen hasilnya melimpah namun pendapatan petani sangat kurang dibandingkan dengan biaya pengelolaan produksi.

Untuk menaikkan pendapatan petani terdapat potensi lain bernilai ekonomi cukup tinggi yang dimiliki desa ini yaitu limbah pertanian. Jerami merupakan limbah pertanian yang banyak ditemukan di daerah persawahan. Dari setiap ha tanaman padi, limbah jerami yang dihasilkan sekitar $5-8$ ton setiap kali panen (10-16 ton/tahun). Oleh petani setelah panen padi, limbah jerami ini hanya dibiarkan menumpuk dan kering lalu dibakar. Padahal limbah ini sebenarnya sangat berpotensi sebagai pupuk organik dengan menggunakan bioaktivator dari cacing tanah (Lumbricus Rubellus) sebagai media untuk pertumbuhannya

Selain limbah jerami terdapat juga limbah kotoran sapi. Sapi selain dagingnya bernilai ekonomi tinggi juga kotorannya (Saha, 2004). Satu ekor sapi setiap harinya menghasilkan kotoran berkisar 8-10 kg per hari atau 2,6-3,6 ton per tahun atau setara dengan 1,5-2 ton pupuk organik sehingga akan mengurangi penggunaan pupuk anorganik dan mempercepat proses perbaikan lahan.

Cacing tanah (Lumbricus Rubellus) dapat digunakan untuk mendegradasi 
kotoran sapi sehingga proses pengomposan tersebut (Vermicomposting) lebih cepat dan lebih singkat terjadi (Mashur, 2001).

Cacing tanah (Lumbricus Rubellus) ini memiliki warna tubuh merah kecokelatan, panjangnya sekitar 2-5 inci. Cacing ini mempunyai banyak kelebihan dibanding cacing jenis lain. Kelebihan dari cacing ini adalah tidak berbau, cepat berkembang biak, tumbuh subur, mempunyai ketahanan hidup yang tinggi, mudah beradaptasi dengan berbagai media yang dipergunakan, dan sangat mudah dibudidaya (Rusmini dkk, 2016)

Hasil akhir dari vermicomposting baik limbah jerami maupun kotoran sapi adalah kotoran cacing (Kascing). Kascing mengandung unsur hara yang lengkap, baik unsur makro dan mikro. Menurut Canatoy (2018), pupuk kascing bersifat netral dengan nilai $\mathrm{pH}$ 6,52. Komposisi kimia kascing meliputi nitrogen $(\mathrm{N})$ $0,63 \%$, fosfor (P) 0,35\%, kalium (K) 0,20\%, kalsium (Ca) 0,23\%, magnesium (Mg) $0,26 \%$, natrium $(\mathrm{Na}) 0,07 \%$, tembaga (Cu) $17,58 \%$, seng (Zn) 0,007\%, manganium $(\mathrm{Mn}) \quad 0,003 \%$, besi $(\mathrm{Fe})$ $0,79 \%$, boron (B) $0,21 \%$, molibdenum (Mo) $14,48 \%$, KTK 35,80 meg/100 mg, kapasitas menyimpan air 41,23\%, dan asam humus 13,88\%, memperbaiki struktur perairan, mengubah aktivitas mikroorganisme tanah (Aira dkk, 2006). Disamping itu kascing mengandung banyak mikroba dan mengandung hormon perangsang pertumbuhan tanaman, seperti giberelin, auksin, dan sitokinin (Buhaira dan Swari, 2013). Sedangkan cacing tanah merupakan sumber protein sangat tinggi sekitar $76 \% .17 \%$ karbohidrat, $45 \%$ lemak, dan abu 1,5\% (Flora, 2014).

Kualitas kascing jauh lebih baik dibandingkan pupuk organik lainnya (Sinda et al., 2015). Aplikasi pupuk kascing juga berpengaruh nyata dalam meningkatkan jumlah daun, berat tajuk segar, dan berat tajuk kering pada tanaman sawi hijau (Sinda et al., 2015). Aira dkk, (2006) mengatakan bahwa Vermicomposting dapat mempercepat laju mineralisasi bahan-bahan organik. Beberapa enzim yang terlibat di dalam dekomposisi bahan organik adalah dehidrogenase, protease, glukosidase, dan fosfatase (Albanel dkk, 1988). Vermikompos menghasilkan dua manfaat utama, yaitu biomassa cacing tanah dan vermikompos itu sendiri (Lazcano dkk, 2008).

Usaha pengomposan dengan teknologi vermicomposting merupakan salah satu usaha agribisnis yang dapat dilakukan oleh petani sebagai sumber 
pendapatan baru dan dapat dilakukan oleh ibu-ibu rumah tangga dan anggota keluarga lainnya secara berkelompok sehingga dapat menumbuhkan partisipasi perempuan dalam usaha perekonomian di desa. Melalui model ini diharapkan dapat berlangsung sistem pertanian terpadu melalui pemanfaatan limbah pertanian untuk pupuk organik yang dapat meningkatkan kesuburan tanaman, peningkatan produksi dan peningkatan pendapatan petani dan peternak

\section{B. METODE PENELITIAN}

Kegiatan ini dilaksanakan dalam lima (5) tahapan, yaitu:

\section{Sosialisasi Program Vermicomposting}

Kegiatan ini diawali dengan melakukan koordinasi dengan Kepala Desa Massila dan Ketua Gapoktan tentang ha-hal yang berkaitan dengan kegiatan Pengabdian Kepada Masyarakat (PKM) yang berhubungan dengan budidaya cacing dan pupuk Kascing. Ketua Gapoktan memilih anggota kelompok tani Mamminasae yang terdiri atas beberapa dusun, sebagai peserta pelatihan (Gambar 1)

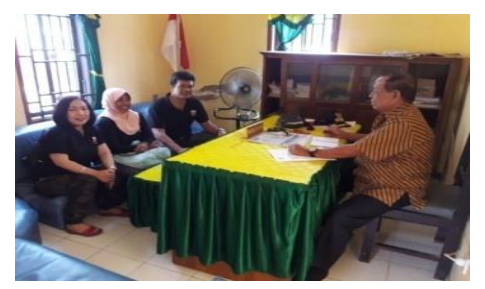

Gambar 1 Sosialisasi program

\section{Waktu dan Tempat Pelatihan}

Kegiatan ini dilaksanakan pada bulan Mei s/d Juli 2020 bertempat di desa Massila, Kecamatan Patimpeng, Kabupaten Bone. Pada kegiatan ini peserta pelatihan diberi materi tentang budidaya cacing mulai dari pembuatan kandang, pemeliharaan, panen sampai dengan aplikasi di lapangan (Demplot) pengaruhnya terhadap pertumbuhan tanaman.

\section{Pelaksanaan Pelatihan}

Tahapan pelaksanaan pelatihan (Gambar 2) meliputi: persiapan media yaitu jerami padi dan kotoran sapi, pembuatan kandang/rak cacing, pembibitan cacing, penggantian mediapemeliharaan cacing-pengendalian hama dan penyakit-pemanenan kascing, pengemasan dan aplikasi kascing pada Tanaman

\section{(Pendampingan Kegiatan}

Kegiatan pendampingan dilakukan dalam rangka menjadi wirausaha baru yang lebih professional dalam mengelola usaha taninya mulai dari manajeman usaha, izin usaha sampai kepada jaringan pemasaran, sehingga pendapatan petani dapat meningkat

\section{Aplikasi Kascing pada Tanaman}


Hasil Vermicomposting berupa pupuk kascing dianalisis di laboratorium untuk melihat kandungan unsur haranya dan selanjutnya diaplikasikan di lapangan dalam bentuk demplot untuk melihat pengaruhnya terhadap pertumbuhan dan produksi tanaman.

\section{HASIL DAN PEMBAHASAN}

\section{Limbah Pertanian untuk Media Cacing}

Media yang digunakan dalam pelaksanaan percobaan adalah limbah

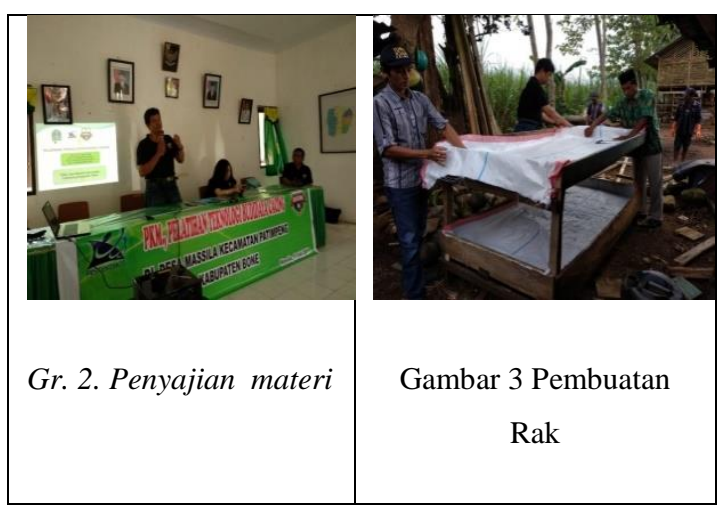

pertanian dari jerami padi dan kotoran sapi. Kedua limbah pertanian ini sangat banyak dijumpai dilokasi pedesaan.

Limbah pertanian berupa kotoran sapi dan jerami padi sangat berpotensi dijadikan sebagai bahan organik penyubur tanah. Bahan organik dapat memperbaiki sifat fisik, kimia dan biologi tanah. Pupuk organik sangat bermanfaat bagi peningkatan produksi pertanian baik kualitas maupun kuantitas, mengurangi pencemaran lingkungan, dan meningkatkan kualitas lahan secara berkelanjutan (Blasi And Maso, 2007). Namun proses pengomposan secara alami untuk mendapatkan pupuk organik memerlukan waktu yang cukup lama, sekitar 8 minggu dimana proses ini kurang efisien (Simanungkalit, dkk. 2006). Sedangkan hasil percobaan yang dilakukan oleh kelompok tani Mamminasae dengan menggunakan cacing tanah sebagai Vermicomposting hanya membutuhkan waktu 2 minggu untuk dapat menghasilkan kascing sebagai pupuk organik yang bermanfaat untuk pertumbuhan tanaman

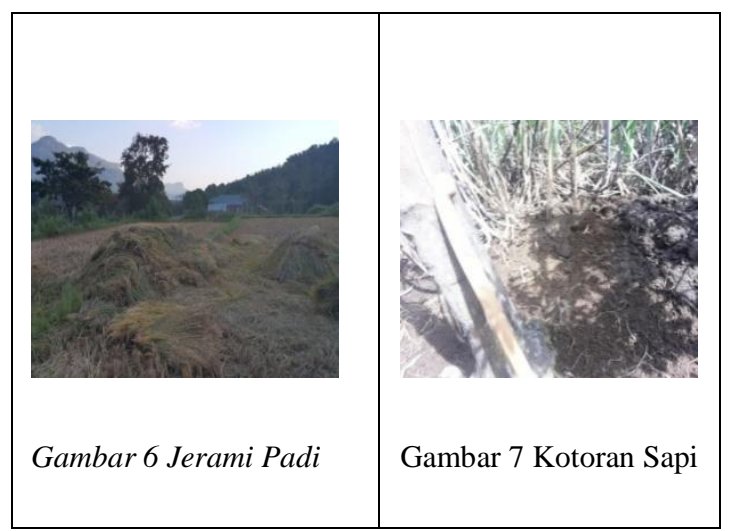

2. Pelatihan Teknologi Composting

\section{Pembuatan Kandang Cacing}

Ukuran tempat pembiakan cacing 8 m x $70 \mathrm{~cm}$ (3 rak/bertingkat) terbuat dari kayu yang menggunakan bambu untuk alasnya dan ternaungi dari hujan dan panas matahari langsung (Gambar 3 dan 4). Bambu tersebut dilapisi karung kemudian diberikan kotoran sapi atau jerami yang sudah dikomposkan dipinggirkan lalu 
dimasukkan bibit cacing (Gambar 5,8, dan 9).

Cacing diberi makan 4 sampai seminggu sekali tergantung habisnya pakan, pakan dikatakan sudah habis bila tanah berubah menjadi kering dan bersifat lempung. Cacing dapat diberi pakan dengan

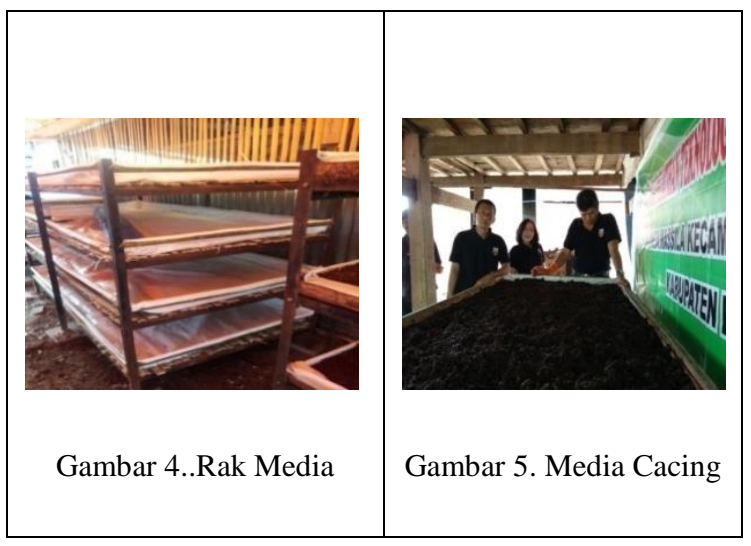

menggunakan kotoran sapi, didiamkan dulu selama 3 hari sampai dengan seminggu sebelum diberikan ke cacing. Cara pemberian pakannya adalah dengan membuat ruang di bagian tengah media lalu

dimasukan ke bagian tengahnya.

\section{Pembibitan.}

Bibit yang digunakan dalam pelatihan ini berasal dari bibit unggul yang dihasilkan oleh peternak cacing dari daerah Galesong kabupaten Gowa Sulsel. Dalam proses pembibitan medianya sudah tersedia berupa kotoran sapi maka bibit cacing sebagian diletakkan diatas media kemudian diamati apakah bibit cacing itu masuk ke dalam media atau tidak. Jika terlihat masuk, baru bibit cacing yang lain dimasukkan. Sebaliknya bila media tidak cocok, cacing akan berkeliaran di permukaan media. Untuk mengatasinya, media harus segera diganti dengan yang baru.

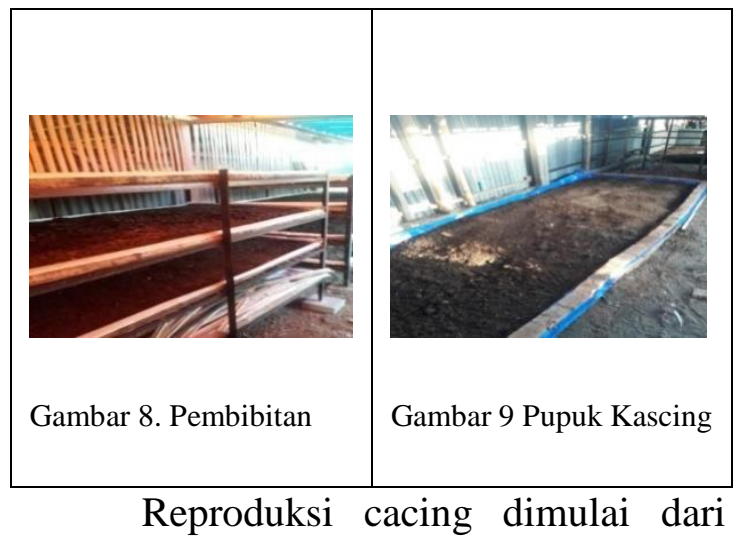

perkawinan sepasang cacing tanah, masing-masing akan dihasilkan satu kokon yang berisi telur-telur. Kokon berbentuk lonjong dan berukuran sekitar $1 / 3$ besar kepala korek api. Kokon ini diletakkan di tempat yang lembab. Dalam waktu 14-21 hari kokon akan menetas. Setiap kokon akan menghasilkan 2-20 ekor, rata-rata 4 ekor. Diperkirakan 100 ekor cacing dapat menghasilkan 100.000 cacing dalam waktu 1 tahun. Cacing tanah mulai dewasa setelah berumur 2-3 bulan yang ditandai dengan adanya gelang (klitelum) pada tubuh bagian depan. Selama 7-10 hari setelah perkawinan cacing dewasa akan dihasilkan 1 kokon.

\section{Penggantian Media}


Media yang sudah menjadi tanah kascing atau yang telah banyak telur (kokon) harus diganti. Supaya cacing cepat berkembang, maka telur, anak dan induk dipisahkan dan ditumbuhkan pada media baru. Rata rata penggantian media dilakukan dalam jangka waktu 2 Minggu.

\section{Pemeliharaan.}

Wadah yang berisi cacing tanah harus dijaga kelembabannya (sekitar 60\%). Jika terlalu kering, lakukan penyiraman bersamaan dengan pemberiaan pakan yang dibasahi, demikian seterusnya. Jika proses tersebut berjalan dengan benar, dalam waktu sekitar sebulan, kotoran sapi akan berubah menjadi pupuk pupuk atau kascing.

\section{Pengendalian Hama dan Penyakit}

Keberhasilan beternak cacing tanah tidak terlepas dari pengendalian terhadap hama dan musuh cacing tanah. Beberapa hama dan musuh cacing tanah yang didapat oleh petani selama pemeliharaan budidaya cacing antara lain: semut, lipan, lalat, tikus, ayam, itik dan pengendalian dilakukan secara manual (mekanis)

\section{Pemanenan Kascing.}

Budidaya cacing tanah ada dua hasil terpenting yang dapat diharapkan, yaitu cacing tanah itu sendiri dan kascing (bekas cacing). Cara pemanenan yaitu Pada siang hari cacing akan banyak bersembunyi dan tidak dipermukaan, karena cacing tidak tahan dengan sinar atau terang. Sehingga pemanenan bisa dilakukan mengeruk kascing yang terdekat pada lapisan atas media dan memindahkan pada kotak yang kosong.

\section{Pemasaran dan penjualan}

Budidaya cacing tanah dapat menghasilkan dua produk sekaligus yaitu cacing dan kascing. Kascing dapat dipasarkan ke toko toko pertanian dan juga ke petani. Sedangkan cacing tanah dapat dipasarkan ke industri farmasi dan kosmetik dan kepada petani yang membutuhkan bibit untuk usaha budidaya cacing,

Budidaya cacing tanah setiap bulan dapat menghasilkan 10 karung kascing (karung $12 \mathrm{~kg}$ ) yang dijual dengan harga $\mathrm{Rp} 20.000 /$ karung X 10 karung $=$ Rp 200.000 untuk luas kandang $8 \times 5 \mathrm{~m}$. Sedangkan produksi cacing sendiri setiap bulan dapat menghasilkan cacing sebanyak $10 \mathrm{~kg}$ cacing/ bulan dengan harga Rp 100.00 X 10 kg = Rp 1.000.000 / bulan + kascing Rp 200.000, sehingga total pendapatan tambahan yang diterima oleh kelompok tani Mamminasae sebesar Rp 1.200.000

\section{Pelatihan Manajemen Usaha Tani}

Materi Manajemen usaha tani yang disampaikan pada kegiatan pendampingan 
kelompok tani meliputi empat pokok penting yakni perencanaan (planning), pengorganisasian (organizing), pelaksanaan (actuating) dan evaluasi (evaluating) yang semuanya ini dapat dilakukan sehingga kegiatan usaha tani dapat berjalan efektif dan efisien

\section{Demplot Aplikasi Kascing}

Sesudah petani memahami dan terampil membuat pupuk Kascing, selanjutnya dibuatkan demplot percontohan pertumbuhan tanaman. Demplot jagung (Gambar 10 dan 11) dilaksanakan di lahan milik anggota kelompok tani Mamminasae sehingga disaksikan oleh anggota kelompok tani lainnya, dengan luasan lahan 0,5 hektar. Hasil pengujian aplikasi pupuk kascing terhadap pertumbuhan tanaman jagung sangat signifikan baik pertumbuhan vegetaif maupun produksi yang dihasilkan. Hal ini sejalalan dengan hasil hasil penelitian menunjukkan bahwa pupuk Kascing memperbaiki pertumbuhan dan meningkatkan produksi tanaman jagung. Menurut Utomo dkk, (2016) menyatakan bahwa untuk dapat tumbuh dengan baik tanaman membutuhkan hara $\mathrm{N}, \mathrm{P}$, dan $\mathrm{K}$ yang merupakan unsur hara esensial. Unsur hara esensial adalah unsur - unsur hara makro (N, P dan $\mathrm{K}$ ) yang diperlukan bagi pertumbuhan tanaman dan meningkatkan produksi serta kualitas produk.

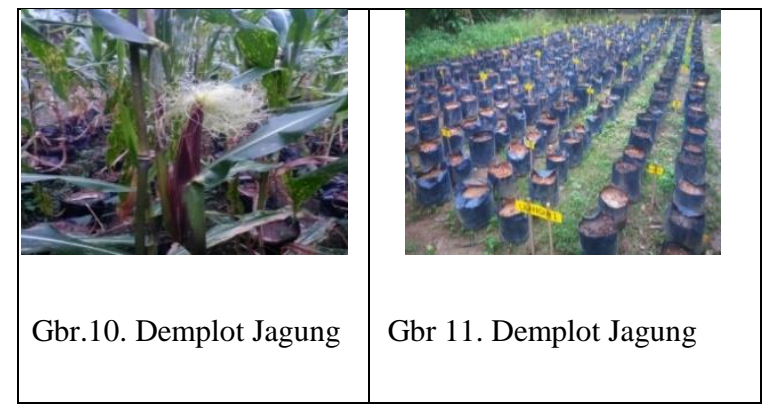

\section{Monitoring dan Evaluasi}

Setelah unit usaha budidaya cacing tanah berjalan, tahapan terpenting berikutnya adalah tahapan monitoring dan evaluasi. Tahapan monitoring dan evaluasi ini dilakukan dengan mengunjungi lokasi usaha yang telah dilakukan oleh anggota kelompok tani mamminasae sasaran untuk memastikan bahwa unit usaha budidaya cacing masih berjalan sesuai dengan prosedur yang baik dan benar yang telah dijelaskan dalam kegiatan pelatihan

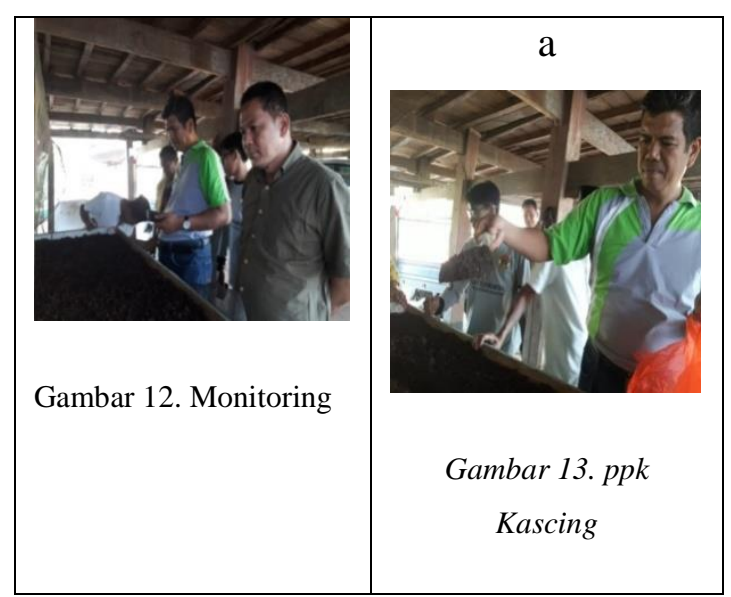




\section{KESIMPULAN DAN SARAN}

Hasil yang dicapai kelompok tani Mamminasae di Desa Massila, Kecamatan Patimpeng, Kabupaten Bone, Sulawesi Selatan Yaitu Anggota kelompok tani Mamminasae telah mampu melaksanakan dan memiliki keterampilan budidaya cacing tanah dengan tahapan kegiatan: pembuatan rak bersusun, pembibitan, penggatian media, pemeliharaan, pengendalian hama dan penyakit, pemanenan cacing dan kascing Terbentuknya unit usaha kelompok tani mandiri yang dapat memperoleh tambahan pendapatan, meningkatkan kualitas hidupnya, agar mereka dapat hidup lebih baik, lebih efisien cara hidupnya, lebih sehat fisik dan lingkungannya.

Budidaya cacing tanah setiap bulan dapat menghasilkan 10 karung kascing (karung $12 \mathrm{~kg}$ ) yang dijual dengan harga $\operatorname{Rp} 20.000 /$ karung $X 10$ karung $=R p$ 200.000 untuk luas kandang 8 X 5 m. Sedangkan produksi cacing sendiri setiap bulan dapat menghasilkan cacing sebanyak $10 \mathrm{~kg}$ cacing/bulan dengan harga Rp 100.00 X $10 \mathrm{~kg}=\mathrm{Rp} 1.000 .000 /$ bulan + kascing Rp 200.000, sehingga total pendapatan tambahan yang diterima oleh kelompok tani Mamminasae sebesar Rp 1.200 .000

\section{DAFTAR PUSTAKA}

Aira, M., Monroy, F., Dominiguez, J. 2006. C to N Ratio Strongly affects Population Structure of Eiseniafetida in Vermicompost Systems. Eur J Soil Biol 42 S 127- S 131.

Albanel, E., Plaixats, J., Cabrero, T. 1988. Chemical Changes During Vermicompost of Sheep Manure Mixed With Cotton Industrial Waste. BiolFertil Soils6 : 266-269.

Blasi, A. B. And Maso, M. A. 2007. Evaluation of Composting as a Strategy for Managing Organik Wastes from a Municipal Market in Nicaragua. Bioresource Technology. Vol. 99 (5120 - 5124).

Buhaira, dan E. I. Swari. 2013. Pertumbuhan dan Hasil Jagung Muda (Baby Corn) pada Perbedaan Dosis Kascing. Jurnal Bioplantae 2(3) : 132-137.

Canatoy, R. C. 2018. Effects of Fertilization on the Growth and Yield of Sweet Corn in Bukidnon, Philippines. Asian Journal of Soil Science and Plant Nutrition 3(2) : 18.

Flora, Esha. 2014. Manfaat dan Khasiat Cacing Tanah. http://indonesianherbal.blogspot.com/2014/03/manfa at-dan-khasiat-cacing-tanah.html, diakses tanggal 26 Februari 2015.

Lazcano, C., Brandon, M.G., Dominiguez, J. 2008. Comparison of the Effectiveness of Composting and Vermicompost for the Biological Stabilization of Cattle Manure. Chemosphere. 72 : 1013-1019.

Mashur 2001. Vermikompos (Kompos Cacing Tanah) Pupuk Organik Berkualitas dan Ramah Lingkungan. Instalasi Penelitian dan Pengkajian Teknologi Pertanian. Mataram.

Saha BC. 2004. Lignocellulose Biodegradation and Applications in 
Biotechnology. In: Lignocellulose Biodegradation. Saha BC, Hayashi $\mathrm{K}$ (Ed.). American Chemical Society, Washington DC. p2-34.

Simanungkalit, Suriadikarta, Didi Ardi, R.D.M. (2006).Pupuk Organik dan Pupuk Hayati. Jawa Barat: Balai Besar Penelitian dan Pengembangan Sumberdaya Lahan Pertanian. Hal 2. ISBN 978-979-9474-57-5.

Sinda, K. M. N. K., N. L. Kartini dan I W. D. Atmaja. 2015. Pengaruh Dosis Pupuk Kascing terhadap Hasil Tanaman Sawi (Brassica juncea L.), Sifat Kimia dan Biologi Pada Tanah Inceptisol Klungkung. Jurnal Agroekoteknologi Tropika 4: 170179.

Utomo, M., Sabrina, T., Sudarsono, Lumbanraja, J., Rusman, B., dan Wawan (2016). Ilmu Tanah: Dasar dasar dan Pengelolaan Prenadamedia Group 